\title{
Interference of heating on the antimicrobial activity and chemical composition of Origanum vulgare L. (Lamiaceae) essential oil
}

\author{
Interferência do aquecimento sobre a atividade antimicrobiana e composição química do óleo essencial de
} Origanum vulgare L. (Lamiaceae)

\author{
Evandro Leite de SOUZA ${ }^{1 *}$, Tânia Lúcia Montenegro STAMFORD², Edeltrudes de Oliveira LIMA, \\ José Maria BARBOSA FILHO ${ }^{4}$, Márcia Ortiz Mayo MARQUES
}

\begin{abstract}
Origanum vulgare L. (oregano), Lamiaceae, essential oil has a variety of biological properties and its antimicrobial activity has received a renewed interest for use in food conservation. The aim of this study was to evaluate the interference of heating on the antimicrobial activity and chemical composition of $O$. vulgare essential oil. The antimicrobial activity of the essential oil kept at room temperature and exposed to different heating temperatures $\left(60,80,100\right.$ and $120^{\circ} \mathrm{C}$ during 1 hour) was evaluated by observing antimicrobial effectiveness at absolute concentration and determining MIC values by the solid medium diffusion procedure. The essential oil chemical composition analysis was performed by GC-MS. O. vulgare essential oil showed interesting antimicrobial activity on all assayed microbial strains (Candida albicans, C. krusei, C. tropicalis, Bacillus cereus, Escherichia coli, Staphylococcus aureus, Yersinia enterocolitica, Salmonella enterica, Serratia marcencens), noted by large growth inhibition zones $(30-42 \mathrm{~mm})$. Heating treatment showed no significant interference $(\mathrm{p}<0.05)$ on the essential oil antimicrobial activity, noted by the development of microbial growth inhibition zones with similar or close diameters when evaluating the essential oil kept at room temperature and after exposure to different thermal treatments. MIC values oscillated between 10 and $40 \mu \mathrm{L} . \mathrm{mL}^{-1}$ $\left(20 \mu \mathrm{L} \cdot \mathrm{mL}^{-1}\right.$ for most strains). However, no significant difference $(\mathrm{p}<0.05)$ was noted among the MIC values found for the essential oil aliquots exposed to different temperatures. Moreover, heating did not significantly $(\mathrm{p}<0.05)$ affect the chemical composition of $O$. vulgare essential oil. Monoterpenes, terpenic compounds and sesquiterpenes were found in the essential oil, with carvacrol (68.06-70.27\%) and p-cymene (12.85-15.81\%) being the compounds found in the highest amounts. These results showed the thermal stability and intense antimicrobial properties of $O$. vulgare essential oil and support its possible concomitant use with heating temperatures in order to reach microbial safety in foods.
\end{abstract}

Keywords: Origanum vulgare L.; essential oil; heating; antimicrobial activity; chemical composition.

\section{Resumo}

O óleo essencial de Origanum vulgare L. Lamiaceae (orégano) apresenta variadas propriedades biológicas, de modo que seu potencial antimicrobiano tem despertado interesse para uso na conservação de alimentos. Este estudo objetivou avaliar a interferência de diferentes tratamentos térmicos $\left(60,80,100\right.$ e $120^{\circ} \mathrm{C} / 1$ hora) sobre a efetividade antimicrobiana e composição química do óleo essencial de $O$. vulgare. A efetividade antimicrobiana do óleo essencial exposto aos diferentes tratamentos térmicos foi avaliada através da observação de sua atividade antimicrobiana em concentração absoluta e através da determinação da sua CIM utilizando-se a técnica de difusão em meio sólido. O estudo da composição do óleo essencial foi realizado através de GC-MS. O óleo essencial apresentou intensa atividade antimicrobiana sobre todas as amostras microbianas ensaiadas (Candida albicans, C. krusei, C. tropicalis, Bacillus cereus, Escherichia coli, Staphylococcus aureus, Yersinia enterocolitica, Salmonella enterica e Serratia marcencens) mostrando amplos halos de inibição do crescimento microbiano (30 a $42 \mathrm{~mm}$ ). O aquecimento do óleo essencial de $O$. vulgare não mostrou interferência $(\mathrm{p}<0.05)$ sobre sua propriedade antimicrobiana, sendo observado o desenvolvimento de halos de inibição do crescimento microbiano com diâmetros similares ou aproximados quando ensaiadas a alíquota do óleo essencial mantido em temperatura ambiente e as alíquotas submetidas a diferentes temperaturas de aquecimento. Os valores de CIM encontrados para o óleo essencial de $O$. vulgare oscilaram entre 10 a $40 \mu \mathrm{L} \cdot \mathrm{mL}^{-1}\left(20 \mu \mathrm{L} \cdot \mathrm{mL}^{-1}\right.$ para a maioria das amostras), entretanto nenhuma diferença significativa $(\mathrm{p}<0.05)$ foi notada para os valores de CIM encontrados para as alíquotas do óleo essencial exposto a diferentes temperaturas. Ademais, o aquecimento não interferiu significativamente $(\mathrm{p}<0.05)$ sobre a composição química do óleo essencial. A análise da composição do óleo essencial mostrou a presença de monoterpenos, compostos terpênicos e sesquiterpenos, de modo que carvacrol (68,06 a 70,27\%) e p-cimeno (12,85 a 154,81\%) foram os compostos encontrados em maiores concentrações no óleo essencial. Estes resultados mostram a estabilidade térmica do óleo essencial de $O$. vulgare e suporta seu possível uso concomitante com altas temperaturas em sistemas de conservação de alimentos.

Palavras-chave: Origanum vulgare L.; óleo essencial; aquecimento; atividade antimicrobiana; composição química.

Recebido para publicação em $7 / 3 / 2007$

Aceito para publicação em 7/8/2007 (002359)

${ }^{1}$ Laboratório de Microbiologia de Alimentos, Departamento de Nutrição, Centro de Ciências da Saúde, Universidade Federal da Paraíba - UFPB, CEP 58059-900,

João Pessoa - PB, Brasil, E-mail: evandroleitesouza@ccs.ufpb.br

2 Centro de Ciências da Saúde, Departamento de Nutrição, Universidade Federal de Pernambuco - UFPE, Recife - PE, Brasil

3 Laboratório de Micologia, Departamento de Ciências Farmacêuticas, Centro de Ciências da Saúde, Universidade Federal da Paraíba - UFPB, João Pessoa - PB, Brasil

${ }^{4}$ Laboratório de Tecnologia Farmacêutica, Universidade Federal da Paraíba - UFPB, João Pessoa - PB, Brasil

${ }_{5}^{5}$ Centro de Pesquisa e Desenvolvimento de Recursos Genéticos Vegetais, Instituto Agronômico de Campinas, Campinas - SP, Brasil

${ }^{*}$ A quem a correspondência deve ser enviada 


\section{Introduction}

Food conservation has progressively become more complex since consumers are demanding more natural foods with low levels of chemical additives, however, with the convenience of a long shelf-life (CAMPO et al., 2003; LEUSCHNER; ZAMPARINI, 2002). The increasing interest in replacing chemical food preservatives has impelled the search for plant products with antimicrobial properties (FARIAS-ALVES et al., 2003; QUILES et al., 2002; SOUZA et al., 2005). Plants are characterized for possessing a wide variation of volatile compounds, being many designated as Generally Recognized as Safe - GRAS (OZCAN; ERKMEN, 2001; VALERO; SALMERÓN, 2003).

Origanum vulgare L. (Lamiaceae) is a very versatile plant with diaphoretic, carminative, antispasmodic and antiseptic properties and has been used in traditional health care for a long time. Moreover, its biological properties have been explored by agricultural, pharmaceutical, culinary and cosmetic industries as flavoring substances in foodstuffs, alcoholic beverages and perfumes because of its spicy fragrance (ALIGIANIS et al., 2001; VAN DEN DOOL; KRATZ, 1963). O. vulgare essential oil has been known as an interesting source of alternative antimicrobial compounds to be applied in food conservation (CHUN et al., 2005; NOSTRO et al., 2004; SOUZA et al., 2007).

Since essential oils are the volatile fraction present in plants (BURT, 2004; VILJOEN et al., 2003), doubts on their thermal stability when submitted to heating temperatures traditionally used in food conservation could arise. Although some researchers (PERIAGO; PALOP; FERNANDEZ, 2001; POL; KROMMER; SMID, 2002) have evaluated the interference of some classical and/or innovative procedures used in food conservation on the antimicrobial effectiveness of essential oils, there is a lack of data about the interference of different thermal treatments on their antimicrobial properties.

A number of potential synergists have been suggested for concomitant use with essential oils in food conservation: low $\mathrm{pH}$, low water activity, chelators, low oxygen tension, nisin and anaerobic packaging (PERIAGO; MOEZELAR, 2001; PERIAGO; PALOP; FERNANDEZ, 2001; TASSOU; DROSINOS; NYCHAS, 1996), although not all of these have been researched in food products. On the other hand, $\mathrm{NaCl}$ showed an antagonistic effect on the antimicrobial activity of some phytochemicals found in essential oils used in the food industry (ULTEE et al., 2000).

This study was carried out with the purpose of evaluating the interference of different thermal treatments on the antimicrobial activity and chemical composition of $O$. vulgare essential oil.

\section{Materials and methods}

\subsection{Essential oil}

O. vulgare essential oil was obtained from Ferquima Ind. e Com. Ltda. (Vargem Grande Paulista, São Paulo, Brazil) and its quality parameters (appearance, color, purity, odor, density $-20^{\circ} \mathrm{C}$, refraction index $-20^{\circ} \mathrm{C}$ ) were described in an accompanying technical report. This supplier extracts essential oils in an industrial scale by the hydrodistillation procedure.

\subsection{Microbial strains}

Candida albicans ATCC 7645, C. krusei ATCC 6258, C. tropicalis MD 37, Bacillus cereus ATCC 11778, Escherichia coli ATCC 8739, Staphylococcus aureus ATCC 6538, Yersinia enterocolitica ATCC 9610, Salmonella enterica ATCC 6017 and Serratia marcencens ATCC 13880 strains were used as trial microorganisms. The strains were supplied by the National Institute of Quality in Health, FIOCRUZ, Rio de Janeiro, Brazil, and by the Institute of Antibiotics, Federal University of Pernambuco, Recife, Brazil. Bacteria and yeast strains stock cultures were kept on, respectively, sterile nutrient and Sabouraud agar slants at $4{ }^{\circ} \mathrm{C}$. Inocula were obtained from overnight cultures (bacteria were grown on nutrient agar slants at $35-37^{\circ} \mathrm{C}$, yeasts were grown on Sabouraud agar slants at $25-28{ }^{\circ} \mathrm{C}$ ) and diluted in sterile PBS to provide a final concentration of $10^{6}$ colony forming units per $\mathrm{mL}$ (CFU.mL ${ }^{-1}$ ) adjusted according to the turbidity of the $0.5 \mathrm{McF}$ arland scale tube.

\subsection{Essential oil treatment}

Aliquots $(1 \mathrm{~mL})$ of the essential oil were put in screw capped glass tubes and kept for 1 hour at room temperature $\left(28^{\circ} \mathrm{C}\right)$ or heating temperatures $\left(60,80,100\right.$ and $\left.120^{\circ} \mathrm{C}\right)$ using a dry block (Dry Block TE 021, Tecnal, Brazil) (TSIGARIDA; SKANDAMIS; NYCHAS, 2000). At the end of the thermal treatment, the aliquots were cooled in an ice bath and immediately submitted to antimicrobial activity and chemical composition analyses.

\subsection{Antimicrobial activity}

The interference of heating on the antimicrobial effectiveness of $O$. vulgare essential oil was evaluated by determining the antimicrobial activity of the essential oil aliquot kept at room temperature and after exposure to different heating temperatures. The essential oil was assayed at absolute concentration (screening) and at different concentrations $\left(160,80,40,20,10,5,2.5\right.$ and $\left.1.25 \mu \mathrm{L} . \mathrm{mL}^{-1}\right)$, in order to determine the Minimum Inhibitory Concentration MIC. The solutions with different concentrations of the essential oil were prepared according to Souza et al. (2007).

The solid medium diffusion technique using filter paper discs was used for screening the antimicrobial activity of $O$. vulgare essential oil. For this, $1 \mathrm{~mL}$ of the microbial suspension (approximately $10^{6} \mathrm{CFU} \cdot \mathrm{mL}^{-1}$ ) was uniformly spread on sterile nutrient (for bacteria) or Sabouraud (for yeasts) sterile agar Petri dishes. After the absorption of the inoculum by the agar, filter paper discs (Whatman n. 1, $6 \mathrm{~mm}$ diameter) were soaked with $20 \mu \mathrm{L}$ of the essential oil and placed on the inoculated agar (ALIGIANIS et al., 2001; BAYDAR et al., 2004). The system was incubated at $37^{\circ} \mathrm{C} / 24$ hours for bacteria and $25^{\circ} \mathrm{C} / 48$ hours for yeasts. At the end of the incubation period, the diameters of the microbial growth inhibition zones were measured using calipers and expressed in millimeters. Positive antimicrobial activity was considered when growth inhibition zones with diameters equal to or greater than $10 \mathrm{~mm}$ were observed. The control included in this assay was essential oil replaced by sterile water.

The essential oil MIC value was determined by the solid medium diffusion technique using wells in the dishes. Initially, $1 \mathrm{~mL}$ of the microbial suspension was uniformly spread on 
sterile nutrient (for bacteria) or Sabouraud (for yeasts) agar Petri dishes. After the absorption of the inoculum by the agar, wells were made using sterile glass tubes ( $6 \mathrm{~mm}$ diameter) and were filled with $50 \mu \mathrm{L}$ of the essential oil solutions (HADACEK; GREGER, 2002; SOUZA et al., 2005). The system was incubated at $35-37{ }^{\circ} \mathrm{C} / 24$ hours for bacteria and $25-28{ }^{\circ} \mathrm{C} / 48$ hours for yeasts. At the end of the incubation period, the MIC was the lowest essential oil concentration showing microbial growth inhibition zones with diameters equal to or greater than $10 \mathrm{~mm}$.

\subsection{Essential oil chemical analysis}

The chemical composition of the essential oil (kept at room temperature and submitted to different thermal treatments) was analyzed using a gas chromatograph (GC) fitted to a mass spectrometer (MS) (GC-MS, Shimadzu QP-5000, Kyoto, Japan) operating in the electron-impact (70 e V, $\mathrm{m} / z$ 40-450) mode; the fused-silica capillary column used was an OV-5, $30 \mathrm{~m}$ long, $0.25 \mathrm{~mm}$ i.d., $0.25 \mu \mathrm{m}$ film thickness (Ohio Valley Special Chemical Inc., USA). The chromatographic conditions were as follows: sample preparation $1 \mu \mathrm{L}$ in $1 \mathrm{~mL}$ of ethyl acetate; injection volume $1 \mu \mathrm{L}$; split ratio 1:20; helium flow rate $1.0 \mathrm{~mL} / \mathrm{min}$; temperature program ramp from 60 to $240{ }^{\circ} \mathrm{C}$ with a gradient of $3{ }^{\circ} \mathrm{C} / \mathrm{min}$ (holding the initial and final temperature for 5 minutes); injector temperature $240{ }^{\circ} \mathrm{C}$; detector temperature $230^{\circ} \mathrm{C}$.

The identification of the essential oil components was performed by the retention indexes (ADAMS, 1995) and comparing their mass spectra with a data bank (System GC-MS, Nist. $62 \mathrm{lib}$ ) and literature (ADAMS, 1995; McLAFFERTY; STAUFER, 1989). Retention indexes were obtained by co-injection with a hydrocarbon $\left(\mathrm{C}_{9}-\mathrm{C}_{24}\right)$ standard mixture using the Van Den Doll equation (VAN DEN DOOL; KRATZ, 1963).

\subsection{Statistical analysis}

Statistical analysis was performed to determine statistically significant differences $(\mathrm{p}<0.05)$ by Student's $t$-test for paired data. For this, the Sigma stat 2.03 computer program was used.

\section{Results and discussion}

Table 1 shows the screening of the antimicrobial activity of $O$. vulgare essential oil kept at room temperature and exposed to different thermal treatments. The essential oil at absolute concentration presented strong antimicrobial effect on all assayed microorganisms, noted by large growth inhibition zones (30-42 $\mathrm{mm})$. The yeast strains had inhibition zones with diameters over $40 \mathrm{~mm}$ for most interactions, presenting higher sensitivity to the essential oil when compared to the bacteria strains. Higher sensitivity of yeasts to essential oils in comparison to bacteria was also found by other researchers (KONNING; AGYARE; ENNISON, 2004; VILJOEN et al., 2003).

Table 2 shows the MIC of $O$. vulgare essential oil kept at room temperature and after exposure to different thermal treatments. MIC values oscillated between 10 and $40 \mu \mathrm{L} . \mathrm{mL}^{-1}$, with 20 and $10 \mu \mathrm{L} \cdot \mathrm{mL}^{-1}$ being the most frequently found MIC values for the bacteria and yeast strains, respectively. MIC values were the same for the essential oil aliquot kept at room temperature and for those submitted to different heating temperatures (60, 80,100 and $120^{\circ} \mathrm{C} / 1$ hour). Different MIC values were observed only against $Y$. enterocolitica, for which the essential oil exposed to $120^{\circ} \mathrm{C}$ presented a MIC value $\left(10 \mu \mathrm{L} \cdot \mathrm{mL}^{-1}\right)$ lower than those of the essential oil kept at room temperature or exposed to 60, 80 and $100{ }^{\circ} \mathrm{C}\left(20 \mu \mathrm{L} . \mathrm{mL}^{-1}\right)$.

Some studies have found effectiveness of $O$. vulgare essential oil in providing a reduction in the microbial population in fish dishes $\left(0.5 \mu \mathrm{g} \cdot \mathrm{g}^{-1}\right)$, eggplant salad (7-21 $\left.\mu \mathrm{g} \cdot \mathrm{g}^{-1}\right)$, vacuum packed ham $\left(5.60 \mu \mathrm{g} \cdot \mathrm{g}^{-1}\right)$, salmon fillets $\left(5 \mu \mathrm{g} \cdot \mathrm{g}^{-1}\right)$ and cod fillets $\left(0.5 \mu \mathrm{g} \cdot \mathrm{g}^{-1}\right)$ (GIL et al., 2002; ISMAIEL; PIERSON, 1990; MEJLHOLM; DALGAARD, 2002). Tsigarida et al. (2000) and Skandamys and Nychas (2003) noted that the use of $O$. vulgare essential oil up to levels of $10 \mu \mathrm{L} . \mathrm{g}^{-1}$ has impelled some organoleptic attributes (e.g. flavor, odor and color) in meat and fish products.

No scientific report was found on the interference of high temperatures (over $60{ }^{\circ} \mathrm{C}$ ) on both antimicrobial effectiveness and chemical composition of $O$. vulgare essential oil. Periago et al. (2001) noted that the use of mild heat treatment $\left(45^{\circ} \mathrm{C}\right.$ for 5 minutes) caused an increase in the antimicrobial effectiveness of carvacrol and thymol ( $\left.45 \mu \mathrm{g} \cdot \mathrm{mL}^{-1}\right)$, phenolic compounds found in O. vulgare essential oil, on Bacillus cereus, providing a decline

Table 1. Screening of the antimicrobial activity of $O$. vulgare L. essential oil kept at room temperature and after exposure to different heating temperatures (results expressed as diameters of growth inhibition zones in millimeters). ${ }^{\mathrm{a}, \mathrm{b}}$

\begin{tabular}{lccccc}
\hline \multicolumn{1}{c}{ Microorganisms } & \multicolumn{5}{c}{ Temperature of exposure } \\
\cline { 2 - 6 } & $\mathrm{RT}$ & $60{ }^{\circ} \mathrm{C}^{\mathrm{c}}$ & $80^{\circ} \mathrm{C}^{\mathrm{c}}$ & $100{ }^{\circ} \mathrm{C}^{\mathrm{c}}$ & $120^{\circ} \mathrm{C}^{\mathrm{c}}$ \\
\hline B. cereus ATCC 11778 & 32 & 32 & 33 & 31 & 32 \\
E. coli ATCC 8739 & 31 & 30 & 31 & 30 & 30 \\
S. aureus ATCC 6538 & 31 & 33 & 32 & 31 & 33 \\
S. enterica ATCC 6017 & 29 & 29 & 30 & 30 & 29 \\
S. marcencens ATCC 13880 & 30 & 30 & 28 & 28 & 29 \\
Y. enterocolitica ATCC 9610 & 33 & 33 & 32 & 31 & 33 \\
C. albicans ATCC 7645 & 40 & 39 & 40 & 38 & 40 \\
C. krusei ATCC 6258 & 42 & 40 & 40 & 42 & 41 \\
C. tropicalis MD 37 & 40 & 41 & 41 & 41 & 40 \\
\hline
\end{tabular}

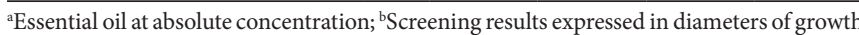
inhibition zones ( $\mathrm{mm}$ ); RT: room temperature; and ${ }^{c} \mathrm{p}<0.05$ versus respective RT according to Student's $t$-test for paired data.

Table 2. Minimum Inhibitory Concentration of O. vulgare L. essential oil kept at room temperature and after exposure to different heating temperatures.

\begin{tabular}{lccccc}
\hline \multicolumn{1}{c}{ Microorganisms } & \multicolumn{5}{c}{$\begin{array}{c}\text { Minimum inhibitory concentration } \\
\left(\mu \mathrm{L} \cdot \mathrm{mL}^{-1}\right)\end{array}$} \\
\cline { 2 - 6 } & $\mathrm{RT}$ & $60^{\circ} \mathrm{C}^{\mathrm{a}}$ & $80^{\circ} \mathrm{C}^{\mathrm{a}}$ & $100^{\circ} \mathrm{C}^{\mathrm{a}}$ & $120^{\circ} \mathrm{C}^{\mathrm{a}}$ \\
\hline B. cereus ATCC 11778 & 20 & 20 & 20 & 20 & 20 \\
E. coli ATCC 8739 & 40 & 40 & 40 & 40 & 40 \\
S. aureus ATCC 6538 & 20 & 20 & 20 & 20 & 20 \\
S. enterica ATCC 6017 & 40 & 40 & 40 & 40 & 40 \\
S. marcencens ATCC 13880 & 20 & 20 & 20 & 20 & 20 \\
Y. enterocolitica ATCC 9610 & 20 & 20 & 20 & 20 & 10 \\
C. albicans ATCC 7645 & 10 & 10 & 10 & 10 & 10 \\
C. krusei ATCC 6258 & 20 & 20 & 20 & 20 & 20 \\
C. tropicalis MD 37 & 10 & 10 & 10 & 10 & 10 \\
\hline
\end{tabular}

RT: room temperature; and ${ }^{\mathrm{a}} \mathrm{p}<0.05$ versus respective RT according to Student's $t$-test for paired data. 
in viable cell counts. Tomaino et al. (2005) reported that heating $\left(80,100,120\right.$ and $180^{\circ} \mathrm{C}$ for 3 hours) of some spice essential oils provided no alteration of their antioxidant properties.

Table 3 shows the GC analysis of $O$. vulgare essential oil kept at room temperature and after exposure to different thermal treatments. The chemical analysis identified 14 compounds in the essential oil, representing values between $95.72-97.36 \%$ of the essential oil total mass $(\mathrm{v} / \mathrm{v})$. The presence of monoterpenes (o-cymene, $p$-cymene, $\alpha$-pinene, myrcene, $\gamma$-terpinene, camphene, limonene), sesquiterpenes (trans-caryophyllene) and terpenic compounds (carvacrol, borneol, dihydrocarveol, cineol) was observed. The compounds found in higher amounts in the essential oil aliquot kept at room temperature were carvacrol (68.06\%), $p$-cymene (15.91\%), $\alpha$-pinene $(2.56 \%)$, myrcene $(2.03 \%), \gamma$-terpinene (1.87\%), trans-caryophyllene (1.33\%) and limonene (1.28\%).

Some compounds found in O. vulgare essential oil (e.g. carvacrol, limonene, $p$-cymene) have been considered to present no risk (named as GRAS or approved food additives) to the health of the consumers and their use as food flavorings has been allowed in the United States and some European countries (BURT, 2004). Carvacrol, which was the compound found in the highest amount in $O$. vulgare essential oil, appears to show no significant or marginal toxic effects in vivo (STAMMATI et al., 1999).

The exposure of $O$. vulgare essential oil to different heating temperatures caused no significant change $(\mathrm{p}<0.05)$ in the chemical composition of the essential oil. Particularly, an increasing percentage of carvacrol, proportionally related to the exposure of the essential oil to higher temperatures $\left(80^{\circ} \mathrm{C}\right.$ $\left.70.27 \% ; 100^{\circ} \mathrm{C} 70.6 \% ; 120^{\circ} \mathrm{C} 74.58 \%\right)$, was noted. Para-cymene (12.85-15.63\%) and $\gamma$-terpinene (1.34-1.76\%), known as carvacrol natural precursors, were also found in significant percentages in the assayed essential oil.

Some compounds found in O. vulgare essential oil have shown antimicrobial properties in laboratorial media and/or foodstuffs, including carvacrol (FERRARA; MONTESANTO; CHIANTESE, 2003; SALGUEIRO et al., 2003), p-cymene (BURT, 2004), myrcene (DUARTE et al., 2005), $\gamma$-terpinene (MARÍN et al., 2004) and limonene (FABIO et al., 2003). Carvacrol has been known as a marker of antimicrobial activity in essential oils, deserving a prominent scientific interest as a natural antimicrobial agent (CHUN et al., 2005; FARIAS-ALVES et al., 2003). Carvacrol increases the passive permeability of the microbial cytoplasm membrane, because of its capability of dissolving in the phospholipid bilayer, aligning itself among the fatty acids and resulting in distortion of the cytoplasm membrane physical structure (DORMAN; DEANS, 2000; LAMBERT et al., 2001).

Our findings related to the non interference of heating temperatures on the antimicrobial properties and chemical composition of O. vulgare essential oil are interesting data that could support its possible concomitant use at high temperatures in food conservation systems. Still, these results encourage further research focusing the interference of other classical or alternative food conservation procedures on the antimicrobial properties of $O$. vulgare essential oils and its main compounds.

\section{References}

ADAMS, R. P. Identification of essential oil components by gas chromatography/mass spectroscopy. Illinois: Allured Publishing Corporation, Carol Stream, 1995.

ALIGIANIS, N. et al. Composition and antimicrobial activity of the essential oil from Origanum species. Journal of Agricultural and Food Chemistry, Washington, v. 49, n. 9, p. 4168-4170, 2001.

BAYDAR, H. et al. Antibacterial activity and composition of essential oils from Origanum, Thymbra and Sartureja species with commercial importance in Turkey. Food Control, Oxford, v. 15, n. 3, p. 169-172, 2004.

BURT, S. Essential oils: their antibacterial properties and potential applications in foods - a review. International Journal of Food Microbiology, Oxford, v. 94, n. 3, p. 223-253, 2004.

Table 3. GC-MS analysis of O. vulgare L. essential oil kept at room temperature and after different thermal treatments for 1 hour (results expressed in percentage of total oil mass). ${ }^{\mathrm{a}}$

\begin{tabular}{|c|c|c|c|c|c|c|c|}
\hline \multirow[t]{2}{*}{ Components } & \multirow[t]{2}{*}{$\mathrm{RI}^{\mathrm{b}}$} & \multirow[t]{2}{*}{$\mathrm{RI}^{\mathrm{c}}$} & \multicolumn{5}{|c|}{ Temperature of exposure } \\
\hline & & & RT & $60^{\circ} \mathrm{C}$ & $80^{\circ} \mathrm{C}$ & $100^{\circ} \mathrm{C}$ & $120^{\circ} \mathrm{C}$ \\
\hline tricyclene & 925 & 925 & 0.28 & 0.28 & 0.28 & 0.24 & 0.20 \\
\hline$\alpha$-pinene & 932 & 932 & 2.56 & 2.47 & 2.42 & 2.25 & 1.78 \\
\hline$\beta$-pinene & 974 & 974 & 0.45 & 0.45 & 0.42 & 0.35 & 0.27 \\
\hline myrcene & 988 & 988 & 2.03 & 1.90 & 1.74 & 1.83 & 1.40 \\
\hline limonene & 1026 & 1026 & 1.28 & 1.29 & 1.27 & 1.19 & 0.96 \\
\hline 1,8-cineol & 1028 & 1028 & 0.92 & 0.87 & 0.86 & 0.88 & 0.84 \\
\hline$\gamma$-terpinene & 1055 & 1055 & 1.87 & 1.76 & 1.65 & 1.60 & 1.34 \\
\hline borneol & 1161 & 1161 & 0.38 & 0.39 & 0.37 & 0.40 & 0.37 \\
\hline dihydrocarveol & 1185 & 1185 & 0.29 & 0.27 & 0.31 & 0.29 & 0.26 \\
\hline
\end{tabular}

${ }^{a}$ Results showed in percentage of total oil mass (v/v); ${ }^{b}$ Reference retention index; ${ }^{c}$ Experimental retention index; RI: retention index; RT: room temperature; and $\mathrm{p}<0.05 \mathrm{versus}$ respective RT according to Student's $t$-test for paired data. 
CAMPO, J. et al. Determination of most bioactive phenolic compounds from rosemary against Listeria monocytogenes: influence of concentration, $\mathrm{pH}$ and $\mathrm{NaCl}$. Journal of Food Science, Chicago, v. 68, n. 6, p. 2066-2071, 2003.

CHUN, S. S. et al. Phenolic antioxidants from clonal oregano (Origanum vulgare) with antimicrobial activity against Helicobacter pylori. Process in Biochemistry, Oxford, v. 40, n. 2, p. 809-816, 2005.

DORMAN, H. J. D.; DEANS, S. G. Antimicrobial agents from plants: antibacterial activity of plant volatile oils. Journal of Applied Bacteriology, Oxford, v. 88, n. 1, p. 308-316, 2000.

DUARTE, M. C. T. et al. Anti-Candida activity of Brazilian medicinal plants. Journal of Ethnopharmacology, Oxford, v. 97, n. 2, p. 305-311, 2005.

FABIO, A. et al. Inhibitory activity of spices essential oils on psychotrophic bacteria. Microbiologica, Bologna, v. 26, n. 1, p. 115-120, 2003.

FARIAS-ALVES, V.; SICCHIROL-LAVRADOS, M. A.; PEREIRA-DE-MARTINIS, E. C. Bacteriocins exposure and food ingredients influence on growth and virulence of Listeria monocytogenes in a model mat gravy system. Journal of Food Safety, Oxford, v. 23, n. 3, p. 201-217, 2003.

FERRARA, L. K.; MONTESANTO, D.; CHIANTESE, C. Origanum majorana L. in medicine and foods. Ingredientia Alimentaria, Milão, v. 2, n. 3, p. 23-25, 2003.

GIL, A. O. et al. A Evaluation of antilisterial action of cilantro oil on vacuum packed ham. International Journal of Food Microbiology, Oxford, v. 73, n. 1, p. 83-92, 2002.

HADACEK, F.; GREGER H. Testing of antifungal natural products: methodologies, comparability of results and essay choose. Phytochemistry Annals, v. 1, n. 1, p. 137-147, 2002.

ISMAIEL, A. A.; PIERSON, M. D. Effect of sodium nitrite and origanum oil on growth and toxin production of Clostridium botulinum in TYG broth and ground pork. Journal of Food Protection, Iowa, v. 53 , n. 11 , p. $958-960,1990$

KONNING, G. H.; AGYARE, C.; ENNISON, B. Antimicrobial activity of some medicinal plants from Ghana. Fitoterapia, Milan, v. 75, n. 1, p. 65-67, 2004.

LAMBERT, R. J. W. et al. A study of the minimum inhibitory concentration and mode of action of oregano essential oil, thymol, and carvacrol. Journal of Applied Microbiology, Oxford, v. 91, n. 3, p. 453-462, 2001.

LEUSCHNER, R. G. K.; ZAMPARINI, J. Effects of spices on growth and survival of Escherichia coli 0157 and Salmonella enterica serovar enteridis in broth model systems and mayonnaise. Food Control, Oxford, v. 13, n. 6-7, p. 399-404, 2002.

MARÍN, S. et al. Effect of essential oils on zearalenone and deoxynivalenol production by Fusarium graminearum in nosterilized maize grain. Food Microbiology, Oxford, v. 21, n. 3, p. 313-318, 2004.

McLAFFERTY, F. W.; STAUFER, D. The Wiley/NBS Registry of Mass Spectral Data. New York: John Wiley Sons, 1989.

MEJLHOLM, O.; DALGAARD, P. Antimicrobial effect of essential oils on the seafood spoilage micro-organisms Photobacterium phosphoreum in liquid media and fish products. Letters in Applied Bacteriology, London, v. 34, n. 1, p. 27-31, 2002.

NOSTRO, A. et al. Susceptibility of methicillin-resistant staphylococci to oregano essential oil, carvacrol and thymol. FEMS Microbiology Letters, Oxford, v. 230, n. 2, p. 191-195, 2004.
OZCAN, M.; ERKMEN, O. Antimicrobial activity of the essential oils of the Turkish plant species. European Food Research and Technology, Munich, v. 212, n. 6, p. 658-660, 2001.

PERIAGO, P. M.; MOEZELAR, R. Combined effect of nisin and carvacrol at different $\mathrm{pH}$ and temperature levels on the variability of different strains of Bacillus cereus. International Journal of Food Microbiology, Oxford, v. 68, n. 1-2, p. 141-148, 2001.

PERIAGO, P. M.; PALOP, A.; FERNANDEZ, P. S. Combined effect of nisin, carvacrol and thymol on the viability of Bacillus cereus heat-treated vegetative cells. Food Science and Technology International, Madrid, v. 7, n. 6, p. 487-492, 2001.

POL, I. E.; KROMMER, J.; SMID, E. J. Bioenergetic consequences of nisin combined with carvacrol toward Bacillus cereus. Innovative Food Science and Emerging Technology, Oxford, v. 3, n. 1, p. 55-61, 2002.

QUILES, J. L. et al. Role of vitamin E and phenolic compounds in the antioxidant capacity, measured by ESR, of virgin olive, olive and sunflower oils after frying. Food Chemistry, Oxford, v. 79, n. 2, p. 461-478, 2002.

SALGUEIRO, L. R. et al. Chemical composition and antifungal activity of the essential oil of Origanum virens on Candida species. Planta Medica, Oxford, v. 69, n. 9, p. 871-874, 2003.

SKANDAMYS, P. N.; NYCHAS, G. J. E. Effect of oregano essential oil on microbiological and physico-chemical attributes of minced meat stored in air and modified atmospheres. Journal of Applied Microbiology, Oxford, v. 91, n. 6, p. 1011-1022, 2001.

SOUZA, E. L. et al. Inhibition action of some essential oils and phytochemicals on the growth of moulds isolated from foods. Brazilian Archives of Biology and Technology, Curitiba, v. 48, n. 2, p. 245-250, 2005.

SOUZA, E. L. et al. Effectiveness of Origanum vulgare L. essential oil to inhibit the growth of food spoiling yeasts. Food Control, Oxford, v. 18, n. 5, p. 409-413, 2007.

STAMMATI, A. et al. Toxicity of selected plant volatiles in microbial and mammalian short-term assays. Food Chemistry and Toxicology, Oxford, v. 37, n. 8, p. 813-823, 1999.

TASSOU, C.; DROSINOS, E. H.; NYCHAS, G. J. E. Inhibition of resistant microbial flora and pathogen inocula on cold fresh fillets in olive oil, oregano and lemon juice under modified atmosphere or air. Journal of Food Protection, Iowa, v. 59, n. 1, p. 31-34, 1996.

TOMAINO, A. et al. Influence of heating on antioxidant activity and the chemical composition of some spice essential oils. Food Chemistry, Oxford, v. 89, n. 4, p. 549-554, 2005.

TSIGARIDA, E.; SKANDAMIS, P.; NYCHAS, G. J. E. Behaviour of Listeria monocytogenes and autocthonous flora on meat stored under aerobic, and modified atmosphere packaging conditions with or without the presence of oregano essential oil at $5{ }^{\circ} \mathrm{C}$. Journal of Applied Microbiology, Oxford, v. 801, n. 2, p. 901-909, 2000.

ULTEE, A. et al. Antimicrobial activity of carvacrol toward Bacillus cereus on rice. Journal of Food Protection, Iowa, v. 63, n. 5, p. 620-624, 2000.

VALERO, M.; SALMERÓN, M. C. Antibacterial activity of 11 essential oils against Bacillus cereus in tyndallized carrot broth. International Journal of Food Microbiology, Oxford, v. 85, n. 1-2, p. 73-81, 2003.

VAN DEN DOOL, H.; KRATZ, D. J. A generalization of the retention index system including liner temperature programmed gas-liquid partition chromatography. Journal of Chromatography, Oxford, v. 11, n. 2, p. 463-467, 1963.

VILJOEN, A. et al. Osmitopsis astericoides (Asteraceae) - the antimicrobial activity and essential oil composition of a Cape-Dutch remedy. Journal of Ethnopharmacology, Oxford, v. 88, n. 2-3, p. 137-143, 2003. 